REVIEW ARTICLE

\title{
The role of motivation in learning foreign languages: towards a global self-identity - a literature analysis
}

\author{
Marta Łockiewicz (1D) \\ Institute of Psychology, Faculty of Social Sciences, University of Gdansk, Poland
}

Multilingualism creates possibilities of personal growth, which influences the sense of self-esteem and self-identity. This paper reviews topics related to its impact on the activity of the individual. The relationship between L2 (understood both as a second and/or a foreign language, with a focus on learning English as a foreign language) linguistic achievement, motivation, intercultural competence, and the development of L2 identity depending on foreign language speaking skills are discussed. Some learners aspire to acquire a "bicultural" identity, which involves 2 versions of the learner: 1) a usually English-speaking, globally involved one, and 2) a local L1-speaking self. Therefore, classroom instruction should include teaching materials focused on the L2 culture, and respect students' aspirations for personal development through foreign language education. Moreover, the students should have control over their own learning, which could be achieved by promoting oracy, studentcentred instruction and cooperative learning.

\section{KEY WORDS}

motivation; self-regulation; foreign languages; global selfidentity 


\section{BACKGROUND}

Speaking foreign languages (L2, L3, etc.), in addition to one's native language (L1), leads to wider educational and professional opportunities, including international mobility. Consequently, multilingualism creates possibilities of personal growth and self-development, which influences the sense of self-esteem and self-identity. In this paper, I will discuss the relationship between L2 linguistic achievement, motivation, intercultural competence, and the development of L2 identity depending on foreign language speaking skills. I will present different models that explain the role of motivation and self in L2 acquisition, and analyse the differences between language learning in children and in adults, as these depend on cognitive, emotional, and social skills, goals, sense of autonomy, etc. Moreover, innovative instruction methods that take into account the learners' self and autonomy will be described. I will focus mostly, though not exclusively, on the situation of learners of English as a foreign language (EFL) ${ }^{1}$, which is a typical context in Poland, as Nakata (2006) argues that "motivation plays a particularly crucial role in an EFL situation where learners are separated logistically and psychologically from the target culture" (p. 19).

The way people learn L2 may be influenced by: 1) similarity between L1 and L2, 2) the learner's age, personality, intelligence, cognitive curiosity, interests, aptitude, learning strategies, the perception of the language learning environment, attitudes toward learning a particular language and/or languages in general, the language course and teacher, 3) the language teacher's personality, knowledge, teaching approach, 4) parents' and peers' influence, 5) the influence of community and society, 6) the learner's motivation, which is influenced by all the aforementioned factors (Al-Qahtani, 2013; Burstall, 1978; Gardner \& Lambert, 1972; Güçlü \& Şahan, 2017; Sparks, Patton, Ganschow, Humbach, \& Javorsky, 2006). In fact, almost all theoretical and practical approaches name motivation as the key factor in learning languages (Al Othman \& Shuqair, 2013; Al-Qahtani, 2013). It is not surprising, as successful communication with other L2 speakers, which assumes spoken and written language production, is the core aim of foreign language education. Motivation leads to production, as it is a basis for biological, cognitive, and social regulation (Ryan \& Deci, 2000).

\section{MODELS OF MOTIVATION TO LEARN FOREIGN LANGUAGES - THE INFLUENCE OF THE SELF-DETERMINATION THEORY}

The L2 learner's motivation can be characterised on a continuum from amotivation, through extrinsic motivation, to intrinsic motivation, that allows one to predict L2 educational outcomes (Noels, Pelletier, Clément, \& Vallerand, 2003). In the self-determination theory (Ryan \& Deci, 2000), intrinsic motivation reflects a human need for exploration and learning, and assumes both readiness and autonomy to engage in an enjoyable, self-satisfying, and self-controlled action. In the context of L2 learning, it refers to the interest in the language itself, taking pleasure in learning its vocabulary, grammar, history, practising reading and writing, or willingness to meet, get to know, and communicate with other speakers of this language. Intrinsic orientation relates to a greater confidence in an individual's perceived, though not necessarily achieved, L2 competence (Kim \& Choi, 2014), which negatively correlates with anxiety, facilitates the willingness to communicate, and, consequently, relates positively to actual L2 competence (Lahuerta, 2014). An extrinsically motivated person treats the activity itself as a means of pursuing other goals (Ryan \& Deci, 2000), which may be unenjoyable and unsatisfying. In the context of L2 learning, extrinsic motivation refers to the interest in using an L2 as a means of achieving an educational or professional goal, e.g. passing obligatory exams, being promoted at work. The willingness and autonomy vary from external regulation that depends on compliance toward teachers, parents, and community, to an integrated regulation that stems from the awareness and synthesis with the self. Therefore, autonomous regulation should be promoted also in extrinsically motivated individuals (Ryan \& Deci, 2000), who engage in certain activities for personal development.

The rationale of the self-determination theory has been employed in the models of motivation to learn foreign languages, some of which I will characterize below.

According to Dörnyei and Ushioda (2011), the history of research on L2 motivation can be divided into four phases: the social psychological period (1959-1990), the cognitive-situated period (during the 1990s), the process-oriented period (at the turn of the century), and the socio-dynamic period (the currently dominant approach). In this section, I shall present three theories: 1) by Gardner $(1985,2001)$, a theory developed in a multilingual environment, 2) by Dörnyei (2005, 2009), a theory considering also the specificity of a monolingual environment, and 3) by Kormos, Kiddle, and Csizér (2011), a theory which is a development of Dörnyei's approach. Gardner (1985) sees motivation as influenced by the integrative (internal) and the instrumental (external) language learning orientation, both of which decrease the likelihood of work avoidance motivation (Engjn, 2009). The SocioEducational Model of Second Language Acquisition developed by Gardner (2001) assumes that External Influences: History (the learner's socio-cultural and personal background), and Motivators (the teachers' instruction methodology, classroom atmosphere), 
influence the factors that comprise Integrative Motivation. Specifically, they impact Integrativeness and Attitudes toward the Learning Situation (but not Motivation). Integrativeness indicates a willingness to learn L2 to identify with an emotionally important L2 community and openness to intergroup differences. Such identification might even lead to withdrawal from an L1 group (Dörnyei, 2003), and is more likely to happen in a multilingual society, or in a country where the learner's L2 is L1. Attitudes toward the Learning Situation are directed at the teacher, the course, the course materials, other students, etc. (Gardner, 2001). Subsequently, both Integrativeness and Attitudes influence Motivation (effort and enjoyment of learning a language), which further influences achievement, rooted in Language Aptitude. Ganschow and Sparks (1996) argue to include the learners' native and foreign language skills in motivation studies. In fact, learners with poorer L1 literacy skills manifest more negative attitudes about L2 learning, but their anxiety and inhibitions may be reduced by practice opportunities, extra instruction, and adjusted grading (Scott, Bell, \& McCallum, 2009). The achievement in formal and informal situations results in linguistic (language proficiency) and nonlinguistic (anxiety, willingness to communicate) outcomes (Bernaus \& Gardner, 2008; Gardner, 2001), which have a direct bearing on language production. Moreover, Bernaus and Gardner (2008) found that Integrativeness, Attitudes toward the Learning Situation (specifically toward the English Teacher and Course Evaluation), and Instrumental Orientation contribute to individual differences in L2 learning motivation, while Motivation and Attitudes toward the Learning Situation influence English Achievement, positively and negatively, respectively.

The discussed model was developed in a multilingual Canadian society (Dörnyei, 2005), where L2 learners communicate with L2 native speakers on a daily basis. However, Masgoret and Gardner (2003) believe that its assumptions can be generalized outside the Canadian environment. A meta-analysis of Gardner and associates' studies revealed that the L2 achievement correlates consistently and positively with integrative and instrumental orientations (Masgoret \& Gardner, 2003). The availability of L2 in the immediate environment did not moderate these relationships. Thus, a need for identification with the L2 community becomes an important motivating factor in L2 learning, even if the learner does not have direct contact with that community.

In fact, the next theory I would like to discuss, the L2 Motivational Self System theory, assumes that L2 becomes a part of an individual's identity (Dörnyei, 2005), which includes: Ideal L2 Self, Ought-to L2 Self, and L2 Learning Experience (Dörnyei, 2005, 2009). Ideal L2 Self is based on integrative aspirations to reduce the perceived discrepancy between the actual and the Ideal Self and to achieve proficiency in L2.
The Ought-to L2 Self represents a more extrinsic motive to meet other people's expectations and avoid potential negative outcomes resulting from a failure to achieve an expected level of proficiency (Dörnyei, 2005, 2009), despite effort taken (Dörnyei \& Ushioda, 2011). L2 Learning Experience refers to executive motives to react to the immediate teaching environment and experience. Ideal L2 Self explains L2 motivation (40\% of the variance, as reported by Dörnyei \& Ushioda, 2011) in multilingual and monolingual language environments, including language globalisation, when an internationally used language, e.g. English, links to a global culture (Dörnyei, 2005), which underlines the importance of self-identity and autonomy for foreign languages learning. When compared to the integrativeness factor as proposed in Gardner's (2001) theory, the ideal L2 self reflects a more basic identification process within the individual's self-concept, rather than an actual or metaphorical integration into an L2 community (Dörnyei, 2003). However, Dörnyei (2005) argues that his theory is highly compatible with previous approaches in the L2 motivation research.

The Ideal and Ought-to selves are effective for motivational purposes if the learner has a developed, reasonable future self, adequately different from the current one, and consistent with the expectations of the learner's family, peer group, and community (Dörnyei \& Ushioda, 2011). A discrepancy between the actual and ideal self state is linked with negative emotions, such as disappointment and sadness (Higgins, 1987). Learners must activate this future self-image regularly in their working self-concept and use procedural, e.g. self-regulatory, strategies (Dörnyei \& Ushioda, 2011). Possible selves trigger certain behaviours, including those stemming from a desire to achieve mastery, thus linking motivation, cognition, and action (Markus \& Nurius, 1986). Such mastery could be related to L2 proficiency, especially if learners have developed reliable L2 Ideal Selves and are proactively involved in improving their language skills.

Four profiles were identified within the L2 Motivational Self System in a group of Hungarian learners of English (Csizer \& Dörnyei, 2005). The least motivated, group 1, manifested no interest in foreign languages, cultures, and language learning. The most motivated, group 4, developed a salient ideal L2 self, associated with a general interest in foreign languages. Group 2 had more positive attitudes toward the L2 culture and community than group 3, which was superior in instrumental aspects and more motivated by the Ought-to L2 self. Neither of the two middle groups developed a strong ideal L2 self. These findings indicate that a general interest in foreign languages results in an increased planned effort to learn. However, as learners' motivational profiles vary according to the specific L2, target languages interfere with the positivity of their attitudes. In the studied group, the preferred language was English. This is not a surpris- 
ing finding, as English has become a "lingua franca" in the contemporary world. However, this preference is not necessarily universal. For example, Chinese university students, though they exhibited a positive attitude towards English and were motivated to study it, believed that their own L1 was superior (Liu, 2011). Moreover, their families did not appreciate their children being able to associate with English culture. It seems that certain cultures are more conducive than others to the development of a self-concept that includes L2, which may depend not only on psychological, but also on social factors, as motivation to learn L2 stems partly from the attitude of the learner's family, peer group, and community towards both L2 and L2 culture. Moreover, the desire to conform to community expectations varies significantly among countries and cultures (Triandis, 2018). This finding indicates a need for further studies on the L2 Motivational Self System in a variety of cultures, as certain modifications to the original theory might be necessary, due to a different cultural background of the learners. Some of the apparently culture-specific factors related to L2 learning motivation and self concept already identified are presented in the following section.

So far, the validity of the L2 Motivational Self System has also been confirmed for Chinese (Li, 2014) and Pakistani (Islam, Lamb, \& Chambers, 2013) learners. Pakistani students identified their future English proficiency with the development and international reputation of their native country (a National Interest factor) (Islam et al., 2013). However, Lamb (2012) did not clearly identify the Ought-to L2 self in a group of adolescents in Indonesia, who were motivated by the Attitudes toward their Learning Experience. Moreover, effort put into studying depended on the teacher, and the Ideal L2 self contributed to L2 learning motivation only in the urban areas (but not rural or provincial areas, where the parental and familial influence was the greatest), but it was not strong enough to persuade students to put effort into learning, though they were benevolently disposed towards English. Likely, students in rural areas were more guided by their desire to fulfil the significant others' expectations, while students in urban areas depended more on self-regulation and aspirations to achieve the Ideal L2 Self level of L2 proficiency. This explanation is consistent with Bender, Fedor, and Carlson (2011)'s study that demonstrated that children from rural areas are more attached to adults, while those from urban ones are more able to self-regulate.

A development of the L2 Motivational Self System is a Directed Motivational Current (DMC; Muir \& Dörnyei, 2013), in which a sequence of organized behaviours leads to a well-defined vision of a personally relevant future self. This allows a high level of motivation to be sustained for a long time, which is necessary for achieving success in language learning, as students become inherently motivated. This happens when this particular vision is actually being realized, for example when learners try to change their lifestyles. In a classroom, a Directed Motivational Current would be introduced via a project assignment, which gives the learners a lot of autonomy and self-control in the selection and execution of the presentation.

Kormos, Kiddle, and Csizér (2011) developed a learner-centred, interactive model of learning language motivation, an extension of Dörnyei's (2005) theory of the L2 motivational self-system, to which it adds goals, social contextual factors, and their interaction. In this approach, motivation consists of interactive personal factors. The hierarchically organised levels include: 1) motivated behaviour, 2) self-guides and attitudes, 3) distal goals of language learning. Motivated behaviour controls effort and persistence in language learning and relates to the actual language learning activity. Future self-guides consist of the Ought-to L2 self (the learners' self-efficacy beliefs and the beliefs of their community members) and the Ideal L2 self (the learners' own beliefs about the value of L2 learning), which are unrelated in secondary school students (but their ideal L2 self is influenced by parental views), but related in university students and adult learners. Distal instrumental and integrative goals include international posture, which is a tendency to interact with other cultures, e.g. work abroad and a non-ethnocentric attitude (Yashima, 2002). The students' desire to become an active member of the world-wide community of English speakers influences their future self-guides, and is the most important learning goal (Kormos et al., 2011).

In Polish studies, Iwaniec (2014) found that intrinsic motivation, motivated behaviour, and the Ideal L2 Self predicted self-regulated language learning. Secondary school learners' goals were associated with knowledge, international orientation, and the importance of English for their professional careers. Parents encouraged their children to study languages. Pawlak (2012) noted that while within a month the reasons of Polish high school students for learning English instrumentality, international posture (the most important ones), the ideal language self, the Ought-to Self, the L2 learning experience and knowledge orientation -remained relatively stable, the intensity of motivation fluctuated, even during one lesson, being higher towards the end. Students were more motivated intrinsically than extrinsically, though external motives were crucial for those students who struggled to pass the finals. Those learners who exhibited long-term goals spent more time on self-study and developing effective learning strategies.

Generally, all the aforementioned theories underline the importance of identification with an L2 speaking community for the effectiveness of L2 learning. Such identification relates to globalisation and exposure to certain lifestyles and communication patterns available through the media, not necessarily 
actual migration, and correlates with L2 achievement. Openness to other cultures and tolerance to diversity are, nevertheless, conducive to choosing international environments, travelling, and work abroad. Identification with an L2 culture facilitates internalisation of the importance of L2 learning, and creating a personally relevant Ideal L2-Self. Therefore, self-controlled and self-regulated behaviours seem crucial for achievement in L2 learning in different age groups.

\section{MOTIVATION TO LEARN FOREIGN LANGUAGES IN CHILDREN, ADOLESCENTS, AND ADULTS}

Students who were exposed to English and/or started formal education in English earlier obtain better grades in English as L2 even as late as college education (Al-Qahtani, 2013). The onset of FL acquisition in pre-school, when children are particularly linguistically sensitive, relates to a higher future FL competence (Olpińska-Szkiełko, 2015). In fact, Hidaka and collaborators (2012) report that the neural foundation for FL processing develops as early as during 3-5 years of age, and Polish 3-5-year-olds differentiated Polish as L1 and English as a Foreign Language discourse (Łockiewicz, Sarzała-Przybylska, \& Lipowska, 2018). As compared to adults, children acquire correct pronunciation more easily, and are less selfconscious about communication in L2 (Ausubel, 1964). Therefore, L2 instruction should start early, before formal L1 literacy instruction begins, so that the young speakers can achieve a feeling of being comfortable when communicating in L2. Preschool FL instruction should aim to develop the young learners' positive motivation, create a base for systematic linguistic work (Komorowska, 2009), and provide exposure to a FL (Komorowska, 2009; Kondrat, 2015).

L2 instruction for young learners uses implicit, fun-focused techniques, such as games, nursery rhymes, and songs (Aguirre, Bustinza, \& Garvich, 2016). In Poland, the Good Start Method for English bases each class on a nursery rhyme to develop L2 literacy skills through multimodal activities (Bogdanowicz, Bogdanowicz, \& Łockiewicz, 2015). Students can suggest their own activities, which increases their autonomy and self-control. Through singing traditional rhymes children share experience with their English-speaking peers and learn about English folklore. Drama activities, e.g. performing in musicals, allows the students to use English meaningfully and appropriately through role-play and cooperation (Lei \& Huang, 2012). As developing their own schoolbooks in L1 impacts the students' meta-knowledge, meta-cognition, meta-learning, and self-awareness about their own production of culture, which facilitates learning competences (Uszyńska-Jarmoc \& Żak, 2013), they could also create their own exercises and/ or coursebooks using L2. The aforementioned techniques are conducive to making L2 an important element of personal development, immersing the learners in a foreign culture, and focusing on selfregulated behaviour, even at a very young age.

This tendency continues in older learners' instruction. Komorowska (2001) claims that adults who study foreign languages are often motivated instrumentally (Azabdaftari, Gharehaghaji, \& Akbari, 2014), which requires long-term planning, sustained motivation, and self-controlled behaviour. Imposing the English officialisation policy (English obligatory as an official language of the institution, both in course instruction and administrative matters) was more appreciated by those administrative officers in a Korean university who were extrinsically motivated and unmotivated than those who were interested in learning about English-speaking countries' cultures (Kim \& Choi, 2014). However, extrinsic motivation, linked with less autonomy in L2 learning and less confidence in speaking competence, was typical in this group.

Adults who learn foreign languages are also motivated by the ability to communicate with peers, learning about a foreign culture, school progress (Ausubel, 1964; Kormos et al., 2011), and the feeling of autonomy (Dickinson, 1995). Graham, Courtney, Tonkyn, and Marinis (2016) reported that adolescents valued learning French as L2 for travel and communication; their self-confidence and progress expectations, however, gradually decreased. Thus, the English classroom should include practical sessions during which students would communicate in English (AlQahtani, 2013) and utilize digitalized technology activities, such as reading stories online (Hsin-Chou, 2013) and virtual world gaming (Kruk, 2016b), which they use in their everyday life. The perceived freedom of choice and personal competence correlate with more self-determined forms of motivation (Noels et al., 2003), as learners employ cognitive, meta-cognitive, and social language learning strategies (AlQahtani, 2013). Cognitive and metacognitive learning strategies mediate between L2 learners' extrinsic and intrinsic motivation and vocabulary learning due to their proactive nature (Zhang, Lin, Zhang, \& Choi, 2017). However, Dörnyei (2003) noted that in educational psychology the term "learning strategy" has been reconceptualised as "self-regulatory learning", which underlines the significance of autonomy and self-control for motivation and learning. Similarly, elderly female learners in South Korea (Kim \& Kim, 2015) were motivated by self-actualization (satisfaction, achievement, enjoyment, and the importance of English in a local environment and worldwide), the Ideal L2 Self, the Ought-to L2 Self, face-saving, and instrumentality (related to the desire to pass an exam), and demotivated by the pressure of external exam taking, even though they were preparing for a national external exam. The learners with an un- 
attainable Ideal L2 Self assessed environmental and internal factors related to English as L2 learning as negative, and learning English as increasingly difficult, and lost their self-confidence. Thus, the ideal L2 self might be either a motivating or demotivating factor, depending on whether it is both challenging and realistic. Moreover, even in situations when L2 instruction is ostensibly focused on passing exams, the role of L2 in a learner's identity and intrinsic motivation are most important for L2 achievement.

Certain differences in teaching strategies designed for younger and older learners stem mostly from cognitive, emotional, and social developmental changes. Adolescents, as compared to children, process information faster and more accurately, think abstractly and hypothetically, can focus attention purposefully, and develop their interests (Obuchowska, 2001). This cognitive development allows them to set long-term goals and organise their activeness accordingly. Thus, adolescents and adults may base their L2 education on instrumental goals of better career opportunitiessimilar factor in every age group, though, is the need for self-regulation and self-control.

\section{MOTIVATION TO LEARN LANGUAGES - THE ROLE OF THE TEACHER}

Children are motivated by the teachers' kindness (Ausubel, 1964; Komorowska, 2001), adolescents by their competence; they value lessons with an attractive textbook that covers interesting topics, which they can choose themselves (Komorowska, 2001).

Motivation may change during a single lesson and/ or a course of lessons. This is influenced by factors connected to the lesson (e.g. attractiveness and difficulty), learners (e.g. age, abilities), and school (e.g. timetable, workload) (Kruk, 2016a). A process model of L2 motivation involves generating, sustaining, and evaluating motivations and actions, which has been conceptualized in three stages, involving different motivational influences: choice motivation (attitudes towards the L2 and its speakers), executive motivation (sense of autonomy, self and social image related to the quality of the learning experience, knowledge and use of self-regulatory strategies), and motivational retrospection (self-concept beliefs, e.g. self-confidence and self-worth) (Dörnyei, 2003). Thus, to initialize and sustain motivation, a supportive atmosphere, materials relevant for the learners, increasing the learners' goal-orientedness, promoting cooperation and selfmotivating strategies, and encouraging positive retrospective self-evaluation that allow the learners to take control over their learning process should be used.

Unfortunately, teachers sometimes prefer traditional over innovative strategies for English instruction (Bernaus \& Gardner, 2008). Traditional strategies are more teacher-centred than student-centred, and focus on the elements and structure of the language instruction, e.g. dictation, grammar, listening, and reading exercises, translation, addressing questions to the whole class. This approach uses the IRE teaching exchange model: initiation (a teacher's (closed) question) - response (a student's (recall) answer) - evaluation (a teacher's feedback: correct/incorrect) (Alexander, 2012). It does not reflect the natural flow of conversation in everyday life and limits the learners' possibility to express their thoughts. Innovative strategies (Bernaus \& Gardner, 2008) are more studentcentred and based on activities in which students interact with each other and the teacher to solve problems and complete projects, e.g. pair work conversations, small group work, games, self-evaluation, teacher evaluation. However, in the reported study only those strategies which were recognised by the students influenced their motivation and attitudes. Therefore, teachers should assess their students' perceptions of the used strategies, as only perceived, not actual use is effective. The innovative strategies reflect dialogic teaching, which uses 5 principles: collectivity, reciprocity, support, cumulation, and purposefulness (Alexander, 2010). This type of instruction, in which teachers and students cooperate, communicate in an authentic way, and students talk to learn and learn to talk (Alexander, 2010), serves to promote students' oracy skills, which contribute to developing literacy, reasoning, communication, learning, self-advocacy, active citizenship (Alexander, 2012), social functioning, and intercultural competence skills, which would have a positive impact on intrinsic motivation through integrative orientation. The promotion of language teaching methods that support the independence of thought, evaluation, and action has been advocated by the Council of Europe (Coste, North, Sheils, \& Trim, 2003). When teachers use open lesson planning, authentic, not simulated, linguistic communication in L2 is possible (Żylińska, 2003). However, Graham, Courtney, Tonkyn, and Marinis (2016) found no relation between the learners' attitudes to, and self-efficacy for, learning French as L2 and receiving either an oracy (focus on speaking and listening) or a literacy (focus on reading and writing) instruction. Despite this lack of difference, the participants reported that they wanted more fun/games, more speaking/ interaction and more group work to be included in the class instruction. All these activities are characteristic for an oracy approach. Possibly, the students did not recognize the innovative strategies used, which diminished their impact on attitudes, as Bernaus and Gardner (2008) suggested. More research is needed in this area to determine the effectiveness of the oracy approach to foreign language learning.

Another student-centred teaching strategy is cooperative learning, in which students work in small teams throughout the semester (each team usually consists of 4 members), and which is based on the 
rules of positive interdependence and individual accountability (Kagan \& Kagan, 2009; Ning \& Hornby, 2014). Even though the students carry out team assignments, they are assessed individually to appreciate individual effort (Kagan \& Kagan, 2009). Cooperative learning increased intrinsic (but not extrinsic) motivation in university students, giving them a sense of accomplishment, competence, self-control, and autonomy (Ning \& Hornby, 2014). Moreover, the students receive meaningful feedback from teachers and peers, and more positively experienced cooperation, as the personal success of each learner (through representing the team) benefited the entire team.

To conclude, L2 learning motivation can be influenced by teaching materials, methodology, and the teacher's competence. Autonomy-support strategies are particularly successful in fostering both motivation level and educational attainment (Vibulphol, 2016). The use of this approach, as contrasted with a teacher-focused one, allowed learners' motivation to be initiated and maintained, as opposed to decreasing to no activity at all.

\section{MOTIVATION, CULTURAL COMPETENCE, AND BICULTURAL SELF-IDENTITY}

L2 learning is a linguistic, social and cultural activity, which requires the assimilation of some elements of the L2 culture (Dörnyei, 2003). The learners develop an intercultural competence, while remaining members of their own culture. Linguistic and cultural competences in L1 and L2 influence and complement each other (Coste et al., 2003).

The willingness to communicate in L2 depends on: one's perceived communication competence, greater interest in international affairs, occupations, and activities, while an international orientation influences motivation to study L2, which links to self-confidence (Yashima, Zenuk-Nishide, \& Shimizu, 2004). Integratively oriented learners study L2 for cultural purposes (Azabdaftari et al., 2014), for example to learn more about the foreign culture and to interact with L2 native speakers (Graham et al., 2016). Learning an L2 in order to develop knowledge, travel abroad, and develop friendships (the latter to a smaller degree) are related to the feelings of competence and autonomy (Noels et al., 2003), which facilitate motivation to learn L2 and final linguistic achievement.

Using a comparison with a foreign culture, the learners understand better their own culture and language, and become more open to different approaches (Kapica-Curzytek, 2003), thus reconstructing their own identity. Diminishing ethnocentrism and increasing tolerance play an important role in the cooperation and understanding between people from different cultures, and facilitate open communication.
The oracy-oriented approach to language instruction reflects the facilitation of dialogic skills. The intercultural method of instruction develops both linguistic and intercultural and intracultural skills (Żylińska, 2003). Congruence between extrinsic and intrinsic motives and goals promotes acculturation (that is adaptation to a dissimilar culture) to the L2 culture ( $\mathrm{Ru}$ benfeld, Sinclair, \& Clément, 2007). Intercultural motives of learners in L2 acquisition have been reflected in modern theories on the notions of international posture (cf. Yashima, 2002), integrativeness (cf. Bernaus \& Gardner, 2008; Gardner, 2001), and ideal L2 self (cf. Dörnyei, 2005, 2009).

Sustained learning requires the recognition of the personal importance of language acquisition, as students who internalized the reason for L2 learning reported being more comfortable and persevering in their work (Noels et al., 2003). A way of internalizing the necessity of studying L2 is to include it in the Ideal L2 Self. Currently, L2 motivation is reconceptualised and reconstructed using contemporary notions of self and identity (Al Othman \& Shuqair, 2013; Ushioda \& Dörnyei, 2009), which are included in all models of motivation to learn foreign languages discussed in the paper (see Table 1). Nowadays, most people develop a global, or a "bicultural" identity, in addition to their local one, for example through exposure to the media, and identify themselves with a worldwide culture (Arnett, 2002). Such a global identity allows them to communicate with people from diverse cultures, either in person or online. This can be achieved usually through learning English as L2 in the globalised multilingual world (Lamb, 2004). A bicultural identity involves 2 versions of the learner: 1) an English-speaking, globally involved one, and 2) a local L1-speaking self. However, the process of developing such identity might be culture-dependant. For example, Chinese students who took an English course in New Zealand had a stronger L2 Ideal Self that those who studied in China (Li, 2014). Interaction with native or fluent speakers may facilitate imagining oneself as a proficient L2 user. The relationships between L2 learning motivation, ideal L2 self, ought-to self, and other, sometimes culturally specific influences vary between cultures and age groups. The studies discussed in this paper generally emphasize the importance of a learner's belief in the personal relevance of L2 learning, aspiration to identify with the L2 community, and selfregulation for L2 achievement. However, self-control and autonomy might be less crucial for learners from collectivistic, as compared with individualistic, cultures, as they would be more dependable on expectations of their significant others. Therefore, this issue requires more studies in different countries.

To conclude, students themselves generally manifest a positive approach to foreign languages they study, and aspire to develop personally, which often includes striving toward a global ideal self-identity, 
Table 1

Models of L2 motivation and the learner's identity

\begin{tabular}{llll}
\hline No. & \multicolumn{1}{c}{ Reference } & \multicolumn{1}{c}{ Model } & \multicolumn{1}{c}{ Motivation and identity } \\
\hline 1. & Gardner $(1985,2001)$ & $\begin{array}{l}\text { Socio-Educational Model of } \\
\text { Second Language Acquisition }\end{array}$ & $\begin{array}{l}\text { Need for identification with L2 community } \\
\text { (Integrativeness) }\end{array}$ \\
2. & Dörnyei $(2005,2009)$ & L2 Motivational Self System & $\begin{array}{l}\text { L2 included in learner's identity (Ideal L2 } \\
\text { Self and Ought-to L2 Self) }\end{array}$ \\
& $\begin{array}{l}\text { Kormos, Kiddle, and } \\
\text { Csizér (2011) }\end{array}$ & $\begin{array}{l}\text { Interactive model of learning } \\
\text { language motivation }\end{array}$ & $\begin{array}{l}\text { L2 included in learner's identity (self- } \\
\text { guides: Ideal L2 Self and Ought-to L2 Self) }\end{array}$ \\
\hline
\end{tabular}

that would incorporate L2 linguistic proficiency and intercultural competence. As a higher interest in other cultures relates to a more salient ideal L2 self, classroom instruction should also include materials and exercises focused on increasing the students' familiarity with a different culture. Parental encouragement and positive disposition toward L2 are also crucial, especially in younger learners. Moreover, the students should be given more control over their own learning, which could be achieved by promoting oracy, student-centred instruction and cooperative learning.

\section{ENDNOTE}

1 The acquisition of a language as a foreign language refers to the learners having contact with L2 through schooling, as their L1 is a language of instruction and is used in the society. There is either a limited or no possibility at all to communicate and interact with L2 native speakers. The acquisition of a language as L2 refers to the learners having contact with L2 through schooling and in everyday life, as their L2 is a language of instruction and is used in the society as its L1. Constant communication and interaction with $L 2$ native speakers is possible and/or required. In this paper, I will refer to L2 instruction for both of these cases.

\section{References}

Aguirre, D., Bustinza, D., \& Garvich, M. (2016). Influence of Songs in Primary School Students' Motivation for Learning English in Lima, Peru. English Language Teaching, 9, 178-191.

Alexander, R. (2010). Speaking but not listening? Accountable talk in an unaccountable context. Literacy, 44, 103-111. https://doi.org/10.1111/j.17414369.2010.00562.x

Alexander, R. (2012). Improving oracy and classroom talk in English schools: achievements and challenges. Paper presented at the DfE seminar on Oracy, the National Curriculum and Educational Standards.
Al Othman, F. H. M., \& Shuqair, K. M. (2013). The Impact of Motivation on English Language Learning in the Gulf States. International Journal of Higher Education, 2, 123-130.

Al-Qahtani, M. F. (2013). Relationship between English Language, Learning Strategies, Attitudes, Motivation, and Students' Academic Achievement. Education in Medicine Journal, 5, 19-29.

Arnett, J. J. (2002). The psychology of globalization. American Psychologist, 57, 774-783.

Ausubel, D. P. (1964). Adults versus Children in Second-Language Learning: Psychological Considerations. Modern Language Journal, 48, 420-424.

Azabdaftari, F., Gharehaghaji, N., \& Akbari, M. H. (2014). Motivation in Learning English among the Paramedical Sciences Students in Iran: Finding a Job or Grabbing a Culture? Research \& Development in Medical Education, 3, 9-13. https://doi. org/10.5681/rdme.2014.004

Bender, S. L., Fedor, M. C., \& Carlson, J. S. (2011). Examining protective factors and risk factors in urban and rural Head Start preschoolers. Journal of Community Psychology, 39, 908-921. https://doi. org/10.1002/jcop.20477

Bernaus, M., \& Gardner, R. C. (2008). Teacher motivation strategies, student perceptions, student motivation, and English achievement. Modern Language Journal, 92, 387-401. https://doi.org/10.1111/j.15404781.2008.00753.x

Bogdanowicz, M., Bogdanowicz, K. M., \& Łockiewicz, M. (2015). The Good Start Method for English. Metoda Dobrego Startu we wspomaganiu rozwoju i uczeniu się dzieci rozpoczynających naukę języka angielskiego [Good Start Method and the facilitation of development and learning of children who start to learn English]. Gdańsk: Wydawnictwo Harmonia.

Burstall, C. (1978). Factors Affecting Foreign-Language Learning: a Consideration of Some Recent Research Findings. In V. Kinsella (Ed.), Language Teaching and Linguistics: Surveys (pp. 1-21). Cambridge: Cambridge UP.

Coste, D., North, B., Sheils, J., \& Trim, J. (2003). Europejski system opisu ksztatcenia językowego: uczenie się, nauczanie, ocenianie [Common European 
Framework of Reference for Languages: Learning, Teaching, Assessment]. Białystok: CODN.

Csizer, K., \& Dornyei, Z. (2005). Language Learners Motivational Profiles and Their Motivated Learning Behavior. Language Learning, 55, 613-659.

Dickinson, L. (1995). Autonomy and Motivation: a Literature Review. System, 23, 165-174.

Dörnyei, Z. (2003). Attitudes, Orientations, and Motivations in Language Learning: Advances in Theory, Research, and Applications. Language Learning, 53, 3-32. https://doi.org/10.1111/1467-9922.53222

Dörnyei, Z. (2005). The Psychology of the Language Learner: Individual Differences in Second Language Acquisition. Mahwah, NJ: Lawrence Erlbaum Associates Publishers.

Dörnyei, Z. (2009). The L2 motivational Self System. In Z. Dörnyei \& E. Ushioda (Eds.), Motivation, language identity and the L2 self (pp. 9-42). Clevedon, UK: Multilingual Matters.

Dörnyei, Z., \& Ushioda, E. (2011). Teaching and researching motivation. Harlow: Pearson Education.

Engjn, A. O. (2009). Second language learning success and motivation. Social Behavior and Personality, 37, 1035-1042. https://doi.org/10.2224/ sbp.2009.37.8.1035

Ganschow, L., \& Sparks, R. L. (1996). Anxiety about foreign language learning among high school women. Modern Language Journal, 80, 199-212. https://doi.org/10.2307/328636

Gardner, R. C. (1985). Social psychology and second language learning. The role of attitudes and motivation. London: Edward Arnold.

Gardner, R. C. (2001). Language Learning Motivation: The Student, the Teacher, and the Researcher. Texas Papers in Foreign Language Education, 6, 1-18.

Gardner, R. C., \& Lambert, W. (1972). Attitudes and motivation in second-language learning. Rowley, MA: Newbury House.

Graham, S., Courtney, L., Tonkyn, A., \& Marinis, T. (2016). Motivational trajectories for early language learning across the primary-secondary school transition. British Educational Research Journal, 42, 682-702. https://doi.org/10.1002/berj.3230

Güçlü, M., \& Şahan, A. (2017). An overall evaluation of the factors affecting foreign language learning in Turkey. Proceedings of the Multidisciplinary Academic Conference, 133-134.

Hidaka, S., Shibata, H., Kurihara, M., Tanaka, A., Konno, A., Maruyama, S., Gyoba, J., Hagiwara, H., \& Koizumi, M. (2012). Effect of second language exposure on brain activity for language processing among preschoolers. Neuroscience Research, 73, 73-79. https://doi.org/10.1016/j.neures.2012.02.004

Higgins, E. T. (1987). Self-discrepancy: a theory relating self and affect. Psychological Review, 94, 319340. https://doi.org/10.1037/0033-295X.94.3.319

Hsin-Chou, H. (2013). Motivational changes in an english foreign language online reading context. Social
Behavior \& Personality: An International Journal, 41, 715-720. https://doi.org/10.2224/sbp.2013.41.5.715

Islam, M., Lamb, M., \& Chambers, G. (2013). The L2 Motivational Self System and National Interest: a Pakistani perspective. System, 41, 231-244. https://doi.org/10.1016/j.system.2013.01.025

Iwaniec, J. (2014). Motivation of pupils from southern Poland to learn English. System, 45, 67-78. https:// doi.org/10.1016/j.system.2014.05.003

Kagan, S., \& Kagan, M. (2009). Kagan Cooperative Learning. San Clemente, CA: Kagan Publishing.

Kapica-Curzytek, J. (2003). Zagadnienie dialogu kultur w nauczaniu języków obcych [The question of the dialogue between cultures in foreign languages instruction]. Języki Obce w Szkole, 6, 30-33.

Kim, J., \& Choi, J. (2014). English for University Administrative Work: English Officialization Policy and Foreign Language Learning. English Language Teaching, 7, 1-13.

Kim, T. Y., \& Kim, Y. K. (2015). Elderly Korean learners' participation in English learning through lifelong education: Focusing on motivation and demotivation. Educational Gerontology, 41, 120-135. https://doi.org/10.1080/03601277.2014.929345

Komorowska, H. (2001). Metodyka nauczania języków obcych [Methodology of foreign language instruction]. Warszawa: Fraszka Edukacyjna.

Komorowska, H. (2009). Metodyka nauczania języków obcych [Methodology of foreign language teaching]. Warszawa: Fraszka Edukacyjna.

Kondrat, D. (2015). Metody pracy z dziećmi w przedszkolu [Methods of work with children in a kindergarten]. Języki Obce w Szkole, 1, 71-76.

Kormos, J., Kiddle, T., \& Csizér, K. (2011). Systems of goals, attitudes, and self-related beliefs in secondlanguage-learning motivation. Applied Linguistics, 32, 495-516. https://doi.org/10.1093/applin/amr019

Kruk, M. (2016a). Temporal Fluctuations in Foreign Language Motivation: Results of a Longitudinal Study. Iranian Journal of Language Teaching Research, 4, 1-17.

Kruk, M. (2016b). Variations in Motivation, Anxiety and Boredom in Learning English in Second Life. The Eurocall Review, 24, 25-39.

Lahuerta, A. C. (2014). Factors Affecting Willingness to Communicate in a Spanish University Context. International Journal of English Studies, 14, 39-55.

Lamb, M. (2004). Integrative Motivation in a Globalizing World. System: An International Journal of Educational Technology and Applied Linguistics, 32, 3-19.

Lamb, M. (2012). A Self System Perspective on Young Adolescents' Motivation to Learn English in Urban and Rural Settings. Language Learning, 62, 997-1023.

Lei, L. W., \& Huang, C. F. (2012). Learning english through musicals: a case study of social economically disadvantaged aboriginal students in Eastern Taiwan. International Journal of Humanities and 
Arts Computing, 6, 204-210. https://doi.org/10.3366/ ijhac.2012.0049

$\mathrm{Li}, \mathrm{Q}$. (2014). Differences in the Motivation of Chinese Learners of English in a Foreign and Second Language Context. System: An International Journal of Educational Technology and Applied Linguistics, 42, 451-461.

Liu, M. (2011). Current language attitudes of mainland Chinese university students. College Student Journal, 45, 851-861.

Łockiewicz, M., Sarzała-Przybylska, Z., \& Lipowska, M. (2018). Early Predictors of Learning a Foreign Language in Pre-school - Polish as a First Language, English as a Foreign Language. Frontiers in Psychology, 9, 1813. https://doi.org/10.3389/fpsyg.2018.01813

Markus, H., \& Nurius, P. (1986). Possible selves. American Psychologist, 41, 954-969. https://doi. org/10.1037/0003-066X.41.9.954

Masgoret, A. M., \& Gardner, R. C. (2003). Attitudes, Motivation, and Second Language Learning: a Meta-Analysis of Studies Conducted by Gardner and Associates. Language Learning, 53, 167-210. https:// doi.org/10.1111/1467-9922.00227

Muir, C., \& Dörnyei, Z. (2013). Directed Motivational Currents: Using Vision to Create Effective Motivational Pathways. Studies in Second Language Learning and Teaching, 3, 357-375.

Nakata, Y. (2006). Motivation and Experience in Foreign Language Learning. Bern: Peter Lang.

Ning, H., \& Hornby, G. (2014). The impact of cooperative learning on tertiary EFL learners' motivation. Educational Review, 66, 108-124. https://doi. org/10.1080/00131911.2013.853169

Noels, K. A., Pelletier, L. G., Clément, R., \& Vallerand, R. J. (2003). Why Are You Learning a Second Language? Motivational Orientations and Self-Determination Theory. Language Learning, 53, 33-64. https://doi.org/10.1111/1467-9922.53223

Obuchowska, I. (2001). Adolescencja [Adolescence]. In B. Harwas-Napierała \& J. Trempała (Eds.), Psychologia rozwoju człowieka. Charakterystyka okresów życia czlowieka [Psychology of human development. Characteristics of the stages in human development] (pp. 163-201). Warszawa: Wydawnictwo Naukowe PWN.

Olpińska-Szkiełko, M. (2015). Lingwistyczne podstawy uczenia języków obcych na etapie przedszkolnym [Linguistic Fundamentals of Second/ Foreign Languages Teaching at Pre-School Level]. Linguodidactica, 19, 199-212.

Pawlak, M. (2012). The Dynamic Nature of Motivation in Language Learning: a Classroom Perspective. Studies in Second Language Learning and Teaching, 2, 249-278.

Rubenfeld, S., Sinclair, L., \& Clément, R. (2007). Second language learning and acculturation: The role of motivation and goal content congruence. $\mathrm{Ca}$ nadian Journal of Applied Linguistics, 10, 308-322.
Ryan, R. M., \& Deci, E. L. (2000). Self-determination theory and the facilitation of intrinsic motivation, social development, and well-being. American Psychologist, 55, 68-78. https://doi.org/10.1037/0003066X.55.1.68

Scott, K. W., Bell, S. M., \& McCallum, R. S. (2009). Relation of Native-Language Reading and Spelling Abilities to Attitudes Toward Learning a Second Language. Preventing School Failure, 54, 30-40.

Sparks, R. L., Patton, J., Ganschow, L., Humbach, N., \& Javorsky, J. (2006). Native language predictors of foreign language proficiency and foreign language aptitude. Annals of Dyslexia, 56, 129-160. https://doi.org/10.1007/s11881-006-0006-2

Triandis, H. C. (2018). Individualism and collectivism. New York: Routledge.

Ushioda, E., \& Dörnyei, Z. (2009). Motivation, language identities and the L2 self: a theoretical overview. In Z. Dörnyei \& E. Ushioda (Eds.), Motivation, language identity and the L2 self (pp. 1-8). Bristol: Multilingual Matters.

Uszyńska-Jarmoc, J., \& Żak, M. (2013). The first schoolbook - the tool of reproducing culture by the child or the tool of child's participation in culture? Contribution to a double special issue on Early literacy research in Poland, edited by Elżbieta Awramiuk and Grażyna Krasowicz-Kupis. L1-Educational Studies in Language and Literature, 13, 1-18. https://doi.org/10.17239/L1ESLL-2013.01.06

Vibulphol, J. (2016). Students' Motivation and Learning and Teachers' Motivational Strategies in English Classrooms in Thailand. English Language Teaching, 9, 64-75.

Yashima, T. (2002). Willingness to Communicate in a Second Language: The Japanese EFL Context. Modern Language Journal, 86, 54-66.

Yashima, T., Zenuk-Nishide, L., \& Shimizu, K. (2004). The Influence of Attitudes and Affect on Willingness to Communicate and Second Language Communication. Language Learning, 54, 119-152.

Zhang, Y., Lin, C. H., Zhang, D., \& Choi, Y. (2017). Motivation, Strategy, and English as a Foreign Language Vocabulary Learning: a Structural Equation Modelling Study. British Journal of Educational Psychology, 87, 57-74.

Żylińska, M. (2003). Podejście interkulturowe, czyli o konieczności zmian w nauczaniu języków obcych [Intercultural approach, or how we must change the way in we teach foreign languages]. Jezzyki Obce w Szkole, 6, 49-62. 